\title{
Imagining Jesus, with food
}

\author{
MICHEL DESJARDINS
}

\begin{abstract}
This his article applies modern, cross-cultural, anthropologically-grounded food data to the historical Jesus. It explores five themes that have emerged from my research on the intersection of spirituality and food in contemporary life, across religions: food offerings, dietary restrictions, fasting, food prepared for special religious occasions, and charity. The analysis brings together previous historical-critical research on Christian origins and current research on food in order to shed new light on the role of food in a first century Jewish person's life. The result is a more human, possibly more historically-realistic, portrait of Jesus in keeping with broad sectors of religious life across traditions.
\end{abstract}

I imagine Jesus as an adult, early-first-century Jewish male, living in Palestine, of indeterminate sexual orientation, whose religious fervour attracted the attention of his fellow Jews and others in the region, eventually leading to his death at the hands of those who considered him a political threat, and to his deification by those who considered him their way to the divine. Trained as I have been as a scholar of early Christianity I know all too well that only a handful of other phrases, if any, could be safely added to this description of Jesus before scholars enter the realm of speculation. I also know how much academic speculation exists concerning 'the historical Jesus', all of it dependent to some extent on each scholar's worldview (Arnal and Desjardins 1997). There is no access to Jesus without interpretation, and imagination; as long as there are Christians, and scholars of early Christianity, there will be reconstructions of Jesus - to be sure, some more historically credible than others.

This article re-constructs Jesus through the lens of fieldwork I have done in comparative religions - much of it collaboratively with my wife. ${ }^{1}$ Over the past decade, while conducting over 300 interviews with people in Asia, the Middle East, North Africa, Europe, the Caribbean, and Central and North America, we have explored how religious food customs and beliefs help to explain modern 
religious life. Every step in the research has uncovered complexities, ${ }^{2}$ but we have gathered enough material with which to make some historically credible suggestions when looking back, in this case, at the earliest accounts of Jesus. I appreciate that Jesus is presented by the gospel writers as someone who challenged common religious and ritual practices and at times re-defined them in provocative ways, yet there is still much that one can say about him as a typical religious individual in the context of his contemporaries and ours.

Our research, I believe, has some transhistorical relevance. Much as I know how allergic scholars of early Christianity are to applying twenty-first-century data to first-century life, first-century Jews, including Jesus, would not have been radically different from other religious people in our world, or in theirs, when it comes to the religious role of food. That is to say, I am assuming that the information we have gathered from religious individuals has some explanatory power when applied to first-century documents. Here I would like to bring these two worlds together, juxtaposing the life of Jesus portrayed in the earliest Christian texts with the results of the research we have conducted in our own day. ${ }^{3}$

I have organized what follows around five themes that emerged in our crosscultural research: food offerings to the deities; dietary restrictions; fasting; food prepared for special religious occasions; and charity. There are other themes, to be sure, but these five are relevant to most religious people and groups we have encountered and in the literature. Each theme reflects both commonalities and differences between traditions (e.g. Muslim and Jain fasting are more similar than one might imagine, but the specific differences are noteworthy), and within traditions (e.g. Passover typically brings Jews together once a year, but when it comes to food traditions some Jews have more in common with Buddhists than they do with other Jews). What follows is an exploration of early Christian sources on Jesus that fit these themes, in conversation with findings that have emerged from our research.

2 The complexities have made us resist the temptation to publish book-length studies, but together, separately and with others we have published some of our research: Desjardins and Desjardins 2009, 201 2; Desjardins and Mulhern 2015; Desjardins forthcoming; Desjardins $20 \mathrm{I} 2$.

3 Biblical scholarship itself over the last quarter century has increasingly paid attention to food. For pointers to this literature (including studies about early Christians), and to some of the discussions, see MacDonald 2008. 


\section{Food offerings to the deities}

Jesus would likely have believed in the existence of a single all-powerful deity, and also in a plethora of spirits that filled the particular construction of the world he inherited and created. Exactly how he navigated that complex world has been much studied, with varied and conflicting conclusions. Religious individuals commonly find ways to personalize the tradition in which they find themselves. I have met Muslims in south-central Java, for instance, who combine belief in Allah with worship of the Sea Goddess, and vegetarian Hindu priests in Bali who happily consume ducks. Jews in Jesus' day would have had their own ways of addressing their spirit world, and Jesus would have been no exception.

One thing is clear: the central Jewish cult of his day placed priority on animal and plant offerings at the Jerusalem Temple; that is to say, cultic officials solicited God's favour through blood, smoke, and other sacrificial substances. There is no reason to doubt that, growing up, Jesus would have taken all this for granted, just as a Roman Catholic today would be unlikely to question transubstantiation, or a Cuban santera the power of cigar smoke to draw the saints to her.

The gospel writers do not stress that aspect of Jesus' devotion, but there is the occasional reminder of its presence. In the Lukan account Jesus is first brought to the Temple by his parents shortly after his birth ('for their purification'), at which point his parents pay for food offerings to be made on his behalf $(2: 22-4)$. In a different narrative, when Jesus vents his anger at the commodification of sacrifice by driving some of the moneychangers and animal merchants out of their stalls in the Temple (John 2:I3-I6; Matt. 21:I 2-I 7; Mark I I:I 5-I 9; Luke I 9:45-8), the context assumes that these business people were there to serve the sacrificial cult.

Another thing is equally clear: some of Jesus' colleagues tried to make sense of his death by conceiving of it as a grand blood sacrifice, even more pleasing to God than the other animal sacrifices (e.g. Heb. 9). God, in the case of both the traditional offerings and Jesus' death, was thought to be enticed by the death of human and non-human animals offered to him. ${ }^{4}$ Underlying all these as a story to remind some Christians that the ultimate human sacrifice, anticipated by the Abraham and Isaac narrative, had been fulfilled by Jesus. For more discussion on the move from Jewish to Jewish-Christian interpretations of the akedah, or sacrifice, see Segal r 987 a. For discussion of the modern Muslim adaptations of the akedah and 


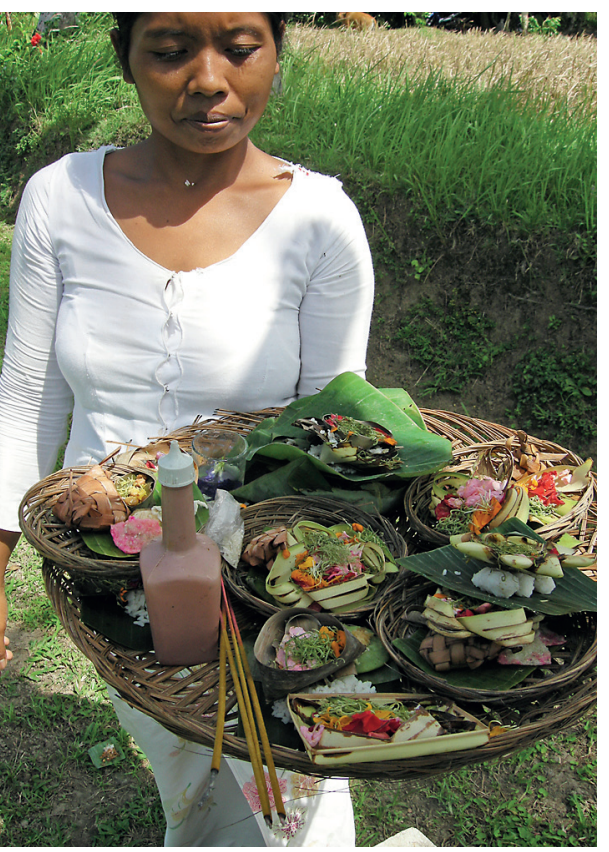

Food offerings to the rice goddess, Bali 2007. Photograph by Michel Desjardins. statements and beliefs is a worldview that understands animal and vegetable products as key conduits between the spirit and human worlds.

Later discussions about food ( Rom. I4-I5; Acts I5), which show a division among Christians regarding the consumption of food that had first been offered to other deities ('idols'), suggest that at least some early Christians continued to conceive of deities as entering food. To eat 'food offered to idols' meant ingesting those deities, and that notion created problems for this new sect, living, as it were, between the times. ${ }^{5}$

That food offerings are religiously important is not surprising by modern, comparative standards. Contemporary religious individuals, across traditions and across the world, frequently and with a great deal of improvisation, reach out to the entire spirit world through food (and drink) offerings, sometimes with blood at the centre of the cult, sometimes with agricultural items. Three of these modern practices help us appreciate Jesus' world differently.

First, it is striking how frequently food offerings are now made throughout the world, not only in and around communal places of worship, but also in and around the home. Food is prepared at home, and offerings typically begin there. There are no references to food offerings in Jesus' home (scarcely anything is said about his home, in any case) or in the homes he enters to dine. If there were such offerings, women would likely have been at the heart of that process, as they so often are today. The absence of women and most domestic activities from these (and many other) stories - Mark I:3 I is a conspicuous exception, perhaps Luke 8:2 as well - does not mean they were absent from Jesus' daily life.

theories of sacrifice through which those practices and narratives can be understood see Desjardins and Mulhern 2015.

5 For more detailed discussions see Segal I987b, and Gooch I 993, who states in his conclusion: 'What was Paul's position concerning idol-food? He urged the Corinthian Christians to avoid it. While Paul abandoned the requirements of the law concerning circumcision and kashrut, Paul did not abandon the covenantal demand for exclusive allegiance to Yahweh.... Since idol-food was found in many contexts, and especially at events marking important social occasions, to avoid idol-food faithfully in the way Paul suggests would have carried significant social liabilities for Christians' ( I 29). 
Second, food offerings are sometimes given only to the good spirits, including the ancestors, enticing them to look more kindly on a particular person. That is certainly the New Testament paradigm: Temple offerings were made to God, not Satan. But across the world today offerings are often given to a wide range of spirits in order to attract some while warding off others. After all, spirits are all potentially dangerous: if food gets the attention of spirits from whom one hopes to benefit directly, why should it not have the same results with other spirits? Throughout Hindu Bali, for instance, we saw food offerings for evil spirits laid just outside the perimeter of the major temples, including the mother temple of Besakih, in order to keep those spirits away from the sacred spaces. Given the significant attention paid to evil spirits in the Mediterranean world in the time of Jesus (see for example Betz i 986, Meyer and Smith 1994), and in the New Testament gospels in particular, it is quite possible that some Palestinian Jewish families and individuals in Jesus' day would have sought to ward off evil by feeding these evil spirits - that is to say, by conducting food exorcisms - or by means of apotropaic rituals involving food.

Third, in some cases (e.g. Hinduism), but not all (e.g. most forms of Buddhism), at least a portion of the food that is offered to the spirits is returned to the donor, spirit-infused. Some food, in other words, ends up with the gods (burnt, eaten by animals, etc.), some is given as thanks/pay to the religious functionaries, occasionally some is given to the needy, and some comes back to the donor. In Jesus' day, donors consumed part of the sacrificial offerings they made at the Jerusalem Temple. The evidence is insufficient for us to know whether people considered that food God-infused, but the Eucharistic ritual that gets constructed following Jesus' death has the donors not only making an offering, but drawing the deity into the food in order to consume it/him. Accordingly, early Christians, in eating Jesus, would likely have been adapting a practice with which they were familiar since childhood. The gods are ingested everywhere in the world; it is the absence of this worldview, not its presence, that requires explanation and wonder.

\section{Dietary restrictions}

So much is made of the Pauline turn away from kosher, and Jesus' occasional challenge to food practices, that it is often forgotten that Jesus himself (not to mention his close friends, including Peter) likely kept kosher. ${ }^{6}$ The Acts io 
account of Peter needing to be told three times by God that he could eat anything, and then having to plead the case to other Christian leaders in Jerusalem (Acts I I), gains force in the context where kosher was still the norm among Christians after the death of Jesus. Moreover, since Jesus lived in a land where not everyone was a Jew and (one always needs to remember) where not all Jews kept kosher, keeping kosher would have had implications for him.

Food restrictions matter. Our research has supported the well-known points that dietary restrictions inevitably reinforce in-group identity ('we' are not like 'them' in the food we eat), lead to in-group divisions ('we' insiders keep to the rules better than 'you' insiders), and help redirect attention repeatedly to the spirit world. One need only think of observant North African Muslim immigrants who now live in France - how their halal food practices divide them from some, and join them to others, both Muslim and non-Muslim.

One thing that I have come to appreciate more these last few years, particularly in conversations with Muslims and upper-caste Hindus, is how profoundly significant food restrictions can be for individuals. I have listened to devout Muslims, for example, tell me that if they eat food forbidden to them God will not hear their prayers because a barrier will develop between them and God. And I have listened to Brahmins tell me how, if they happen to eat food prepared by someone from a lower caste, they will be polluted/infected and will need to undergo a purification ritual to be made right again. ${ }^{7}$

Knowing what I know now - that religiously-imposed food restrictions often mark individuals in fundamental ways - allows me to appreciate more than I did previously, in my academic life as a scholar of early Christianity, the profound transformation that happened when some early Christians decided to abandon food restrictions. The debates in I Corinthians, Galatians, Romans and Acts suggest a break between Paul and Jesus' closest followers that arguably is more visceral than any theological disputes would ever have been. The signal meeting of Paul, his Jewish co-worker Barnabas and his Gentile co-worker Titus, with the observant Christian Jews James, Cephas, and John (Gal. 2:I-IO), and its sequel (2:I I-I 4$)$ suggests as much. ${ }^{8}$

but what comes out of the mouth' (Mark 7:I 5; Matt. I 5:I I; GosThom I 4; see also Acts I I:I-8); and the Lukan Jesus ( го:8) encouraging his colleagues to eat what is set before them when they are spreading the message from place to place. For views of Jesus that do not assume a complete overturning of his culture's food laws see Bockmuehl 2000 and Sanders I990.

7 On this topic in general, see also Dumont I967: chapter 6, and Olivelle 1995.

8 Paul's exclusionary statement in Gal. 2:I 5 , 'We who are Jews by birth and not Gentile sinners', might be grounded in Jewish food purity laws. 
Bracketing the two millennia of Christian activities and thought that have been heavily influenced by Pauline thought, I now also imagine Jesus' itinerant lifestyle to have been more marked by concerns for food purity. In Samaria, in Galilee, and even in Judea, it is likely that Jesus would have been concerned about the food he ingested, and likely also about who prepared it, and he would have assumed that food would hinder or facilitate his access to his God. Statements attributed to Jesus such as that it is 'Not what goes into the mouth that defiles a person, but what

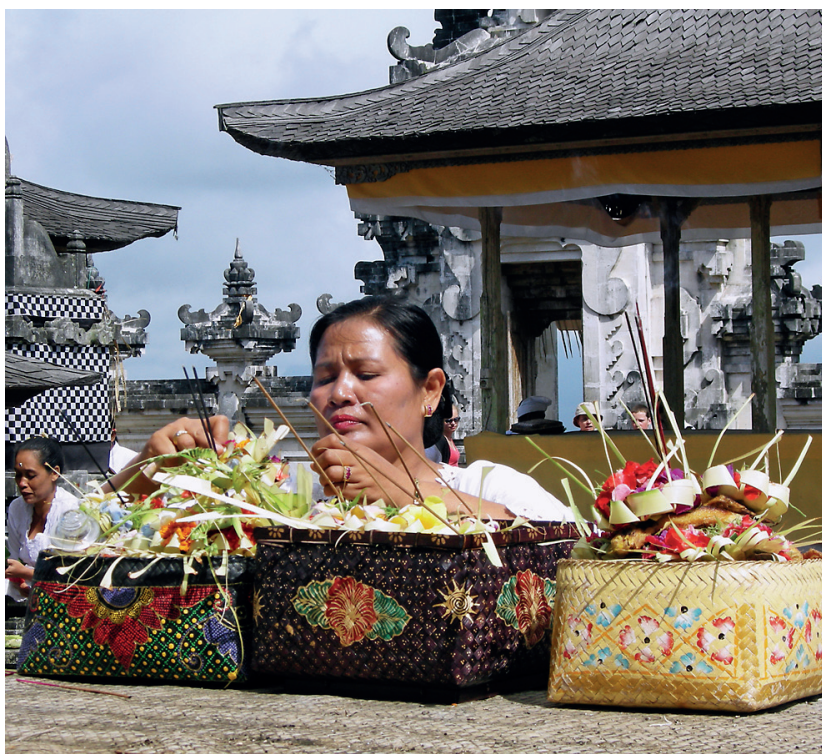

Hindu offering at a temple in Bali, 2007.

Photograph by Michel Desjardins. comes out of the mouth', need not at all suggest that kosher was unimportant to him; they would have been meant, rather, to shock (his colleagues knew the importance of keeping kosher), and to signal the importance of proper behaviour (a person's words should matter even more than kosher).

Jesus might also have eaten vegetarian fare at times - not because he came from a vegetarian tradition, but because omnivorous individuals with meat restrictions who find themselves living in a culture where they cannot always be certain about the source of their food often choose vegetarian options outside the home. Christians, Jews and Muslims have rarely chosen an exclusive vegetarian diet for religious reasons (Seventh-Day Adventists are one notable exception), but the occasional comment about the vegetarian Ebionites ${ }^{9}$ suggests that some early Christians at least were nudged in that direction by kosher concerns. ${ }^{10}$ So it is not simply an argument from silence to imagine Jesus, when

9 E.g. Epiphanius, Haer. 30.22.4.

10 Note Rom. I 4-I 5, which addresses a community controversy over some ('strong') Christians who ate meat and some who didn't (the 'weak'). Paul's view (I4:I3-I6) is that Christians should refrain from eating meat on certain occasions so as not to alienate some in their community; a similar argument is made in I Cor. 8. 


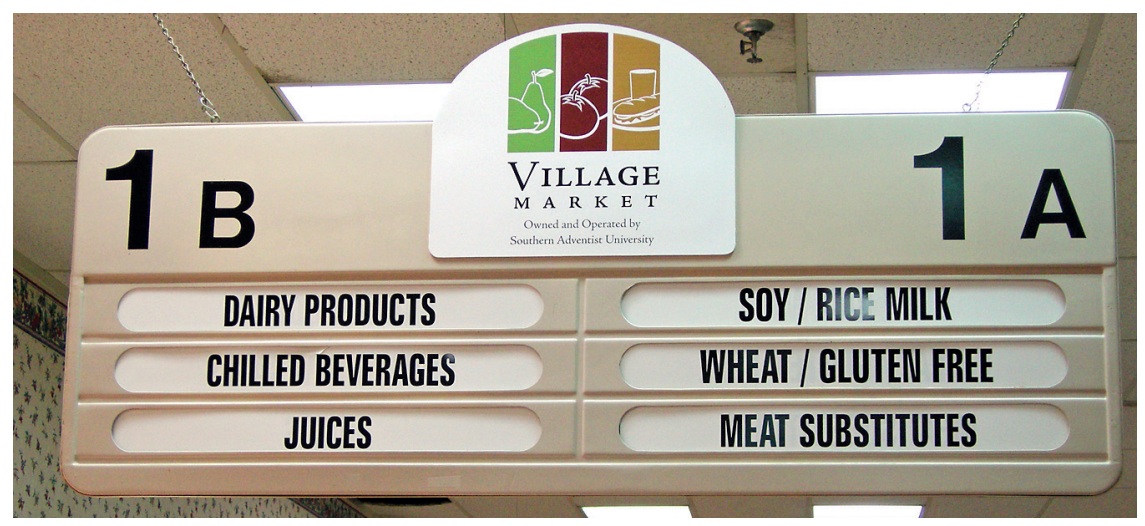

Seventh-Day Adventist grocery store, Chattanooga, USA, 2008. Photograph by Michel Desjardins.

travelling in parts of Galilee and Samaria at least, keeping to a vegetarian diet in order to ensure that he did not break kosher. ${ }^{11}$ Even 'good' Samaritans might not always have had 'safe' treyf. ${ }^{12}$

\section{Fasting}

Early Christian texts have much to say about fasting. Some of it is inconsistent. Yes, you should fast (Jesus fasts during his temptation; some of his closest friends appear to have fasted). No, you shouldn't fast (at least when you have 'the bridegroom' with you, which explains why Jesus and his friends don't fast like John and his group). Yes, you should fast but don't publicize it (don't be hypocrites). The common denominator in the gospels, if one seeks a crossgospel viewpoint, is that Jesus fasted less than other religiously-minded Jews. Again, this concern for fasting is not surprising, given the near-universal presence of fasting among religious individuals in the world. Like prayer, fasting is a vital way for many religious individuals to reach out to the spirit world; once

11 To be sure, meat, because of its cost, would not have been eaten all that frequently, but it was available in Jesus' day. If modern India can be used as an example, the special religious festivals often provide opportunities for even the poor to eat some meat. For information on diet in biblical times, see MacDonald 2008; for the argument that the 'unmoneyed' of the Roman world did eat meat even beyond civic festivals see Meggitt I994.

12 Gaye Tuchman and Harry Gene Levine (1993) popularized the expression 'safe treyf', that is, safe, ritually-impure food for Jews, in exploring the custom of New York Jews eating in Chinese restaurants at the beginning of the twentieth century. 
learned, it is difficult to eliminate as a spiritual practice. Three modern practices shed additional light on Jesus' world.

First, 'fasting' means quite different things to different peoples, across traditions and for each person. It can mean temporary food constraints or no food at all for a certain time period of the day (no meat and animal products, no cooked food, no food and drink all day, etc.); moreover, religious individuals will typically alter the severity and frequency of their fasts to accord with what is happening in their lives.

Imagining Jesus' world to be similar to most situations today, I would expect fasting to accord with the first-century practice in Galilee (or Palestine more generally), whatever that was (we aren't sure), ${ }^{13}$ while also varying quite dramatically from person to person and time to time. I would therefore not expect any saying by Jesus, or anyone else for that matter, to have universal application. By analogy, when Matthew's Jesus tells his group what to do and what to say when they pray (Matt. 6:5-I 5, the 'Lord's Prayer') one should not imagine people discarding their previous ways of praying.

Second, according to data we have gathered in our food research, women typically fast more than men: sometimes they fast for the health of their husband, or for their children, and sometimes they take on the fasting responsibilities for the family because they feel more capable of enduring the suffering. ${ }^{14}$ The contrast drawn in the gospels between John the Baptist (who fasts) and Jesus (who doesn't... at least not quite as much) has gender implications: any advice to reduce fasting would have affected women's religious practices more than those of men. ${ }^{15}$ Here is one instance where John the Baptist's practices, if we are to believe the NT accounts about John and Jesus on this issue, would have been more supportive of women's religiosity than Jesus' practices. Imagine that.

Third, we have found that the start of fasting in a person's life is often a significant rite of passage. Muslim boys and girls who are finally able to fast all the way through the month of Ramadan, for example, undergo a significant change

13 The Day of Atonement, or Yom Kippur, is currently the main Jewish fast day. Religious Jews are encouraged to perform a complete fast (no food, no drink) for 25 hours. The biblical institution of the holiday, however (Lev. 23:26-32), does not mention fasting; it only encourages a complete absence of work and 'afflicting' oneself. Evidence is lacking to determine what fasting practices were current in first-century Palestine.

14 This practice is in tension with what the rabbinic sources tell us about women not having the same ability as men to restrain themselves. For a discussion of these gender stereotypes in early Jewish sources see Satlow I 996.

15 For the importance of fasting for European Christian women in the Middle Ages see Bynum 1987 . 
in group status. It is only natural to think that the same would occur for young Jewish girls and boys in Jesus' day. While much has been said in the past few centuries about Jesus caring for children, it is remarkable that gospel writers are almost entirely silent concerning food rituals such as fasting that would have significantly marked Jesus' life as a child and the lives of other children.

\section{Food prepared for special religious occasions}

I imagine Jesus, like countless other religious individuals over time, to have associated religious festivals, and rites of passage, with tastes and smells, and with the cooking of mothers, sisters, and aunts at those events. Our research overwhelmingly shows that the central element of a religious festival is typically the food; it also shows that women almost always play the leading role in preparing that food. Special religious events in Jesus' life would have been linked to tastes, textures and women.

Currently, rapid cultural changes in every country are having an impact on the transmission of traditional food knowledge: younger generations are losing contact with their traditions, for a variety of reasons. But even now food traditions linked to women linger. I think of an occasion three years ago when my wife and I were invited by one of my students for Passover at her parents' home in Toronto. When we arrived at the home, we could not help noticing the frail appearance of the student's grandmother. My question to her ('Are you OK?') led to a confession that she had been in the hospital until that very morning, when her daughter had arrived to take her out on a day pass. Why? Because only the grandmother knew the recipe for one of the Passover dishes, and the meal had to be exactly 'so' for our presence that evening. The mother, for her part, knew how to make the other dishes, while the daughter could barely boil water.

I have also learned to appreciate the culturally-specific nature of foods served for special religious occasions. We have heard Sephardic Jews, for example, complain about the lack of sensitivity shown by their Ashkenazi brethren to their food customs ('You Sephardim serve rice for Passover?'). Indian Jews in Israel tell the same type of stories. And more generally we have heard religious individuals around the world distinguish themselves from others, even within their own tradition, based on the particular combination of spices used in foods served on special religious occasions. Growing up in a Western Canadian francophone Catholic home, I know how important each family's recipes were in marking Christmas and Easter (e.g. the tourtières or meat pies, the tender ham and spicy pickles). As children it was hard to even conceive of anglophone Catholics having Christmas since their kitchen tables lacked meat pies. 
Three key issues, once again, stand out concerning special religious occasions when I apply our research in this area to the NT representations of Jesus. The first involves rites of passage. These events are universally linked to special food, and sometimes also to the absence of food. I think, for example, of an Indonesian Muslim hair-cutting ceremony which we witnessed, that was carried out in honour of an infant girl during which the hour-long reading from the Qur'an by women ritual experts, combined with the actual cutting of the hair, was followed by a two-hour feast containing foods made from recipes handed down for generations in that particular family.

One would expect the rites of passage linked to Jesus - for example his circumcision, the weddings of his siblings and the deaths of those close to him - to have been marked by food eaten (or not eaten), or offered, before, during, and after the events. The gospel writers, however, provide almost no information about these events. There is the family visit to the Temple to make an offering shortly after his birth. There is also the wedding at Cana, to be sure (John 2:I-II), but what we learn from that story is the unremarkable fact that people drank a lot of wine at weddings. And there is also Jesus' own baptism at the hands of John, followed in the Synoptic gospels with the temptation story and Jesus fasting for a lengthy period of time. The juxtaposition of baptism and temptation presents food as an obstacle to communion with the deity, not as a nourishing, natural completion to this baptismal rite of passage. Baptism is presented as a rite of passage for Jesus, and Christian baptisms in the immediate centuries also carried this force. ${ }^{16}$ In short, the NT gospel evidence concerning rites of passage is slim, with references to food even less pronounced.

Second it is difficult to imagine a major meal, let alone a Passover, taking place in the absence of women. They alone, it is fair to deduce, would know what items to prepare, and how to cook them. How could Jesus and his male friends have had a 'last supper' Passover without women as cooks - and

16 We hear of Paul, for example, fasting for three days before his baptism (Acts 9:9, I9), and occasionally of a 'breaking of bread' that takes place sometime after baptism (e.g. Acts 2:42), but typically the NT gives the impression that baptism had nothing to do with food. The earliest extensive description of a Christian baptism is Hippolytus's Apostolic Tradition (chapters I 5-2 I). As Hippolytus tells it, the initiation process was long and complicated. It began with the candidate's decision to become a Christian, and usually ended three years later with an elaborate baptism ceremony, immediately followed by a Eucharist and the convert's proclamation that he or she would go forth in the world to do good works. The baptism itself was preceded by a two-day fast. 
Third, since it is not only food, but special food, that is linked to most religious occasions, it is also difficult to imagine early Christians gathering for banquets, weddings or Eucharistic services and not serving distinct, family-based dishes and treats. ${ }^{21}$ It is not only the taste of food that would have mattered, but the taste of distinct food that would have sealed the memory of these events. Here again the gospels are silent. ${ }^{22}$ Moreover, when Paul tells the Corinthians to avoid arriving early to eat all the Eucharistic food ( I Cor. I I: I 7-22), he does not remark on the nature of that food. Given the House Church model of gathering in those days, one would expect each family's Eucharist to taste different. I wonder now to what extent the specific food, and spices, served at what became 'the Last Supper' would have possibly served as models for Jesus' colleagues and friends afterwards.

\section{Charity}

All religious traditions encourage food charity, though some now do so more (e.g. Hinduism, Islam) than others (e.g. Buddhism). Food charity has always been important in Judaism. One striking thing we have discovered in our research, though, is the vital connection between food charity and Christianity. When asked to start reflecting on the links between food and religion, Christians, far more than others, invariably start with 'charity', and food is primary.

In this context, what is surprising about the gospels is the relative infrequency of their comments about charity (e.g. Matt. 25:3 I-46; Luke 6:2 I, 25), striking though they are, and also the way some of those comments are concerned only in passing with charity. Yes, there is the famous Parable of the Good Samaritan (Luke I0:30-5; see also Mark I2:28-34; Matt. 22:34-40), but this parable's shock value lies not in the way it encourages charity but in the fact that it was a (despised) Samaritan who paid for food for a stranger. Yes, there is the encouragement to invite the poor to banquets (Luke I 4:I 2-I4), but

about heaven ( I I-I2), and there are almost no physical aspects at all to their thoughts. People want to be rid of problems; what they yearn for is 'no more sickness or pain... peace... happiness and joy... love between people', and so forth. People 'will have responsibilities... and will minister to others', but food doesn't appear at all. How could Americans, I wonder, who love their food, imagine a heaven without it?

21 Three studies that examine early Christian banquets and other special meals, in the context of the broader Greco-Roman world, are Smith 2003, Klinghardt I996, and Taussig 2009 .

22 For example, parables that touch on special meals, such as Luke I 4:7-I I (also Luke I 4: I 5-24; Matt. 22:I-I4; GosThom 64), while charged with layers of meaning, pay almost no attention to the interpretive possibilities of food. 
the message here is to include outcasts in general, with a view to reaping even more rewards at the Day of Judgment. Yes, there is Luke's 'Blessed are you poor' (6:20; followed by the woes to the rich), but we know how Matthew has 'poor in spirit' in a parallel passage $(5: 3)$; in addition, Luke's emphasis in this section is not so much on charity as it is on critiquing the rich (note too that in $17: 7-$ ro Luke's Jesus cares more about enforcing servitude than he does about helping the poor). Yes, Jesus is said to multiply food (in six parallel gospel stories) in order to feed the masses who are listening to him, but there are no similar miracles directed at the poor in general.

This is not to say that the message of feeding the poor is absent from the early Christian representations of Jesus. It is indeed woven through the stories. The point, rather, is that this message is not emphasized to the degree that one might expect, given current Christian practice, and also given the overwhelming connection between food charity and religion in almost all religious traditions. What is remarkable, in short, is this distance between the NT Jesus and what we have found in current religious practice, both Christian and nonChristian. ${ }^{23}$ Perhaps the later Christian focus on charity is out of keeping, at least in intensity, with Jesus' own practices - in the same way that the Christian avoidance of food restrictions does not accord with the kosher practices of Jesus and his closest followers. Given the widespread connections between food charity and religious life in the modern world, however, I suspect that the opposite position has more historical credibility: food charity was probably more significant to Jesus than the gospel narratives suggest.

\section{Conclusion}

What I have presented by superimposing these five themes onto the composite early Christian representation of Jesus is a figure who is less supportive of food charity than one might think, and who shows almost no sensitivity to the value of special food in his religious life, or to fasting, or to kosher, or to reaching out to God through food. Viewed through the modern comparative religions lens this figure, sketched as he is by the gospel writers, is two-dimensional. One would expect Jesus to have reached out with food to God and possibly to other spirits, at the Temple and perhaps also at home. One would expect him to have taken care - at times great care - in determining what food went

23 The proto-communist manifesto in Acts (4:32-5:I I) begins to move us in this direction, and much of the early Christian success in gathering new members becomes linked to charity, concern for widows, and other social matters. 
into his body, and to have felt closer to God in those instances when he kept kosher strictly. Jesus would almost certainly have also carried with him the tastes and other memories connected to special religious events, including rites of passage; his thoughts of God would have likely evoked tastes and smells. And one would expect Jesus to have devoted more attention to feeding the poor, not only when they came

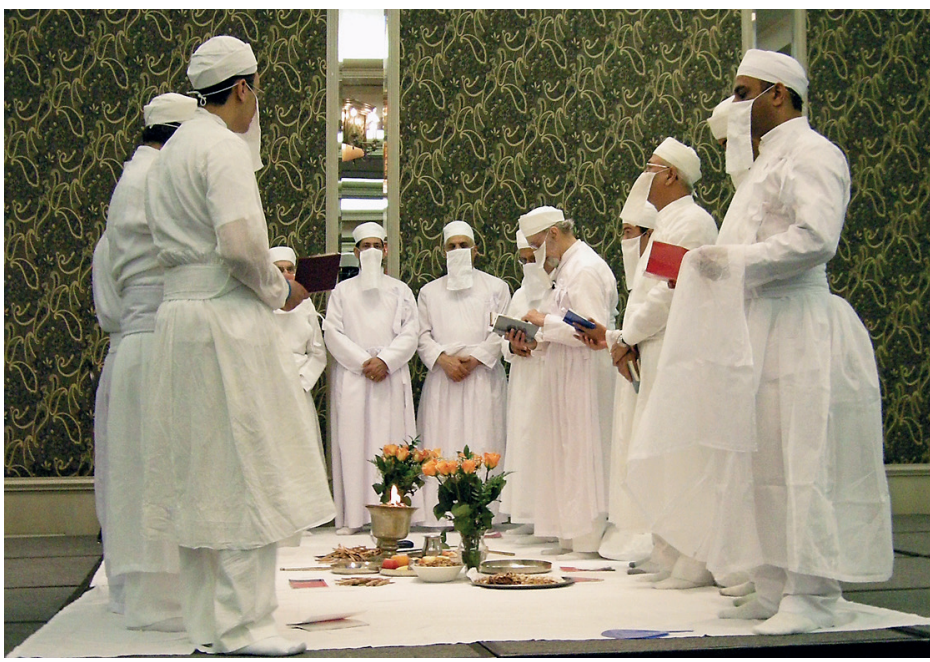

Parsi/Zoroastrian priests enticing angels to descend into the community, by offering them food Toronto, 2008. Photograph by Michel Desjardins. to listen to him talk but also in their everyday lives. A religious figure disconnected in this manner from food seems not fully religious, nor fully human.

Moreover, a fully-human, fully-religious Jesus would have been surrounded by women: preparing and serving his food, eating with him, teasing him to remember tastes and to choose his favourite recipes, preparing his offerings, helping him through fasts and fasting for him, ensuring that his food was acceptable to his religious sensibilities. The question worth asking, in this context, is not whether Jesus had sex with Mary Magdalene, but why the early Christian writers chose to reframe Jesus' religious life in ways that all but obliterated the important work of women, and the profound role of food. ${ }^{24}$ The absence of women contributing to Jesus' religious life through food removes Jesus from this world, and helps me to appreciate the otherworldly nature of the gospel constructions of Jesus. Their imagined Jesus has little to do with everyday religious life.

Fortunately, modern anthropological studies can help bring Jesus back to life, as the human being that he was when integrating food into his religious

24 The gospels contain numerous parables, aphorisms and stories that deal with farming in one form or another. This aspect of the food chain at least was certainly well known by the Jesus represented in early Christian texts, especially the Synoptic gospels and Thomas. 
existence. In that regard, at least, this Jesus is both more mundane and more universally accessible. What he loses when we consider him less disruptive of normal religious life he gains by experiencing religious food rituals similar to a large numbers of religious individuals today. My Jesus now closely resembles a North American Muslim who struggles to eat halal, a Catholic volunteer for the St. Vincent de Paul Society who brings food to the poor, a Hindu woman who fasts to attract the goodwill of particular gods to ensure that her daughter marries well, a Parsi who draws the angels down into his community through food offerings, and a Buddhist who prepares special food for the dead. And like all others who have imagined Jesus to suit their time and disposition, I find my global Jesus compelling. Imagine that.

Michel Desjardins is Professor of Religion and Culture at Wilfrid Laurier University, in Canada. His areas of teaching and research include comparative religions, early Christianity, the academic study of religion, and the scholarship on teaching and learning. He is a $3 \mathrm{M}$ National Teaching Fellow. Dr Desjardins has served on boards and executive committees of several academic societies, including the Canadian Society for the Study of Religion, the American Academy of Religion, and the Canadian Federation of the Humanities and Social Sciences. His most recent co-edited book (with J. Benham Rennick) is The World is My Classroom: Priorities for Globalizing Canadian Higher Education (University of Toronto Press 2013).

\section{References}

Arnal, William E., and Michel Desjardins (eds), I 997. Whose Historical Jesus?

(Waterloo, Wilfrid Laurier University Press)

Betz, Hans Dieter (ed.), I 986. The Greek Magical Papyri in Translation, Including the Demotic Spells, vol. I, 2nd edn (University of Chicago Press)

Bockmuehl, Markus, 2000. Jewish Law in Gentile Churches: Halakhah and the Beginning of Christian Public Ethics (Edinburgh, T\&T Clark)

Bynum, Caroline Walker, I 987. Holy Feast and Holy Fast: The Religious Significance of Food to Medieval Women (Berkeley, Los Angeles, London, University of California Press)

Desjardins, Michel, 2or 2. 'Religious Studies that really schmecks: introducing food to the academic study of religion' in Failure and Nerve in the Study of Religion, ed. William Arnal, Willi Braun, and Russell McCutcheon (London, Equinox), pp. I $47-56$

— forthcoming. 'The Desjardins diet for world religions paradigm loss', in After 'World Religions': Reconstructing the Introductory Course in Religious Studies, ed. Christopher R. Cotter and David G. Robertson (Durham, Acumen)

Desjardins, Michel, and Ellen Desjardins 2009. 'Food that builds community: the Sikh Langar in Canada', Cuizine: The Journal of Canadian Food Cultures/Revue des cultures culinaires au Canada, I (2), <http://www.erudit.org/revue/cuizine/2009/ $\mathrm{vi} / \mathrm{n} 2 / 03785$ Iar.html> 
20r 2. 'The role of food in Canadian forms of Christianity: continuity and change' in Edible Histories, Cultural Politics: Towards a Canadian Food History, ed. Franca Iacovetta, Valerie Korinek, and Marlene Epp (University of Toronto Press), pp. I $16-32$

Desjardins, Michel, and Aldea Mulhern, 20 5 . 'Living sacrifice: rethinking Abrahamic religious sacrifice using field narratives of Eid ul-Adha' in Not Sparing the Child: Human Sacrifice in the Ancient World and Beyond, ed. Vita Daphna Arbel, Paul C. Burns, J. R. C. Cousland, Richard Menkis, and Dietmar Neufeld (London, Bloomsbury T\&T Clark), pp. I 90-2 I 2

Dumont, Louis, I 967. Homo hierarchicus. Essai sur le système des castes (Paris, Gallimard) Feeley-Harnik, Gillian, I 98 I. The Lord's Table: Eucharist and Passover in Early Christianity (University of Philadelphia Press), pp. I 20-7

Gooch, Peter 1993. Dangerous Food: 1 Corinthians 8-10 in Its Context (Waterloo, Wilfrid Laurier University Press)

Klinghardt, Matthias, I 996. Gemeinschaftsmabl und Mablgemeinschaft. Soziologie und Liturgie frühchristlicher Mablfeiern (Tübingen, Francke)

MacDonald, Nathan, 2008. 'Food and diet in the priestly material of the Pentateuch' in Eating and Believing: Interdisciplinary Perspectives on Vegetarianism and Theology, ed. David Grumett and Rachel Muers (London, T\&T Clark), pp. I 7-30

Meggitt, Justin, I 994. 'Meat consumption and social conflict in Corinth', Journal of Theological Studies, 45, pp. I37-4I

Meyer, Marvin W., and Richard Smith (eds), r 994. Ancient Christian Magic: Coptic Texts of Ritual Power (HarperSanFrancisco)

Olivelle, Patrick, I 995. 'Food in India', Journal of Indian Philosophy, 23, pp. 367-80 Sanders, E. P., I 990. 'Jewish association with Gentiles and Galatians 2. I I-I4' in The Conversation Continues: Studies in Paul and John in Honor of J. Louis Martyn, ed. Robert T. Fortna and Beverly R. Gaventa (Nashville, Abingdon), pp. I70-88

Satlow, Michael L., I 996. "Try to be a man”: the Rabbinic construction of masculinity', The Harvard Theological Review, 8, pp. I9-40

Segal, Alan F., I 987 a [1984]. 'The sacrifice of Isaac in early Judaism and Christianity' in The Other Judaisms of Late Antiquity, ed. Alan F. Segal (Atlanta, Scholars Press), pp. 109-30

- $1987 \mathrm{~b}$ [ r 986]. 'Romans 7 and Jewish dietary laws' in The Other Judaisms of Late Antiquity, ed. Alan F. Segal (Atlanta, Scholars Press), pp. I67-94

2004. Life After Death: A History of the Afterlife in Western Religion (New York, Doubleday)

Smith, Dennis, 2003. From Symposium to Eucharist: The Banquet in the Early Christian World (Minneapolis, Fortress Press)

Taussig, Hal, 2009. In the Beginning was the Meal: Social Experimentation and Early Christian Identity (Minneapolis, Fortress)

Tuchman, Gaye, and Harry Gene Levine, r 993. 'New York Jews and Chinese food: the social construction of an ethnic pattern', Journal of Contemporary Ethnography, 22, pp. 382-407 